\title{
Influence of spacing and seed trees on the growth of Pericopsis elata saplings during the first twenty months of a planting trial
}

\author{
Crispin Ilunga-Mulala ${ }^{(1,2)}$, Hulda Hatakiwe ${ }^{(3)}$, Hans Beeckman ${ }^{(4)}$, Olivier J. Hardy ${ }^{(5)}$, \\ Gauthier Ligot ${ }^{(6)}$, Dieu-Merci Assumani ${ }^{(5,7)}$, Léopold Ndjele ${ }^{(1)}$, Nils Bourland ${ }^{(3,4,8)}$
}

(1) University of Kisangani. Faculty of Sciences. Avenue Kitima, 3. BP 2012 Kisangani (DRC). E-mail: crisilunga89@ gmail.com

(2) Université du Cinquantenaire - Lwiro. Faculty of Sciences. Lwiro (DRC). https://orcid.org/0000-0003-4456-0846

(3) Center for International Forestry Research (CIFOR). Kisangani (DRC).

(4) Royal Museum for Central Africa. Service of Wood Biology. Leuvensesteenweg, 13. BE-3080 Tervuren (Belgium).

(5) Université libre de Bruxelles. Faculty of Sciences. Evolutionary Biology and Ecology. CP 160/12. Avenue F. D. Roosevelt, 50. BE-1050 Brussels (Belgium).

(6) Université de Liège - Gembloux Agro-Bio Tech. Terra - Forest is Life. Passage des Déportés, 2. BE-5030 Gembloux (Belgium).

(7) University of Kisangani. Faculty of Renewable Natural Resources Management. Avenue Kitima, 3. BP 2012. Kisangani (DRC).

${ }^{(8)}$ Resources \& Synergies Development Pte Ltd. Raffles Quay 16, \#33-03. Hong Leong Building. Singapore 048581 (Singapore).

Received 26 March 2020, accepted 9 February 2021, available online 18 February 2021.

This article is distributed under the terms and conditions of the CC-BY License (http://creativecommons.org/licenses/by/4.0)

Description of the subject. Pericopsis elata (Fabaceae) is a long-lived light-demanding tree from African rain forests that produces timber of high economic value. Natural populations suffer from overexploitation and a deficit of natural regeneration. Plantations could increase its production and limit the pressure on natural forests. However, we lack knowledge on the influence of spacing and seed tree origin on tree growth to optimize plantation protocols.

Objectives. This study evaluated the impact of sapling density and seed tree origin on the growth in diameter and height of P. elata plants, 20 months after plantation.

Method. Seeds were collected on 19 mother trees in a 400 ha natural stand near Kisangani (DRC). In October 2017, seedlings were transplanted in a Nelder design plantation with three replicates, to compare sapling growth at 10 contrasting plant densities under full sun. Diameter and height increments of 540 plants were analyzed according to local competition and maternal origin using generalized additive models.

Results. Twenty months after planting, height growth peaked at an intermediate density of $47,000 \mathrm{stems} \cdot \mathrm{ha}^{-1}(165.6 \pm 39.2 \mathrm{~cm} \cdot$ year $\left.^{-1}\right)$, while diameter growth peaked at a lower density of 4,200 stems $\cdot \mathrm{ha}^{-1}\left(24.6 \pm 8.3 \mathrm{~mm} \cdot \mathrm{year}^{-1}\right)$. The maternal origin of saplings affected their growth, the coefficients of variation among mother trees reaching $7.6 \%$ and $6.4 \%$ for diameter and height increments, respectively. The initial diameter affected positively diameter growth while the initial height did not influence height growth.

Conclusions. The Nelder design proved useful to assess how plant growth depends both on spacing and genetic factors.

Keywords. Nelder design, Afrormosia, density, genetics, increment, modelling, forest, Africa.

Influence de l'écartement et du semencier sur la croissance des plants de Pericopsis elata durant les vingt premiers mois d'un essai de plantation

Description du sujet. Pericopsis elata (Fabaceae) est un arbre héliophile des forêts tropicales africaines qui produit du bois de grande valeur économique. Ses populations naturelles souffrent de surexploitation et présentent un déficit de régénération naturelle. Les plantations pourraient augmenter sa production et limiter la pression sur les forêts naturelles. Cependant, les connaissances sur l'influence de l'écartement et du semencier sur la croissance des arbres font encore défaut pour les protocoles de plantation. 
Objectifs. Cette étude évalue l'influence de la densité de plantation et du semencier sur les croissances en diamètre et en hauteur des plants de P. elata, 20 mois après la plantation.

Méthode. Les graines ont été collectées sur 19 semenciers dans un peuplement naturel de 400 ha près de Kisangani (RDC). En octobre 2017, les plantules ont été transplantées dans une plantation suivant le dispositif de Nelder en trois répétitions, pour comparer la croissance de 540 plants en plein découvert suivant 10 densités différentes. Les accroissements en diamètre et en hauteur ont été analysés en fonction de la compétition locale et du semencier, à l'aide des modèles additifs généralisés.

Résultats. Vingt mois après la plantation, les croissances étaient maximales, en hauteur $\left(165,6 \pm 39,2 \mathrm{~cm} \cdot \mathrm{an}^{-1}\right)$ à une densité intermédiaire de 47000 tiges $\cdot h^{-1}$, en diamètre $\left(24,6 \pm 8,3 \mathrm{~mm} \cdot \mathrm{an}^{-1}\right)$ à une faible densité de 4200 tiges $\cdot \mathrm{ha}^{-1}$. L'origine génétique des plants a affecté leur croissance, les coefficients de variation entre semenciers ont atteint 7,6\% et $6,4 \%$ pour les accroissements en diamètre et en hauteur, respectivement. Le diamètre initial a influencé positivement la croissance diamétrique mais la hauteur initiale n'a pas affecté la croissance en hauteur.

Conclusions. Le dispositif de Nelder s'est avéré utile pour confirmer la dépendance de la croissance des plants vis-à-vis de l'écartement et mettre en évidence l'influence de facteurs génétiques sur la croissance.

Mots-clés. Dispositif de Nelder, Afrormosia, densité, génétique, accroissement, modélisation, forêt, Afrique.

\section{INTRODUCTION}

The African tropical forest plays a major role in the world, through its multiple ecosystem services (Makana et al., 2011; Fétéké et al., 2015; Tieguhong et al., 2017). However, it is under increasing pressure from shifting agriculture and timber extraction (Bourbier et al., 2013), especially for industrial purposes. Timber is an important source of income for the Congo Basin countries (Toledo et al., 2011). However, its exploitation can have negative impacts on the natural regeneration of some species (Petrokofsky et al., 2015). There is a need to undertake in-depth studies on these commercially important species, to better understand their ecology (Gond et al., 2013), in order to develop sustainable management practices. Efforts to restore degraded forest landscapes are also emerging, such as the AFR100 initiative, seeking to restore one million $\mathrm{km}^{2}$ in Africa (https://afr100.org).

Effective management of production forests requires prior knowledge of species dynamics (Obiang et al., 2010; Vlam et al., 2014), in particular for the most sought-after species with high market value. For several decades, regulatory measures have been taken by the Congo Basin producer countries (Ouédraogo et al., 2014; Ligot et al., 2019) to ensure the sustainability of the resource.

Some authors argue that the establishment of plantations in these countries would guarantee the continuity of timber production after logging, in particular for long-lived light-demanding species (Ngueguim et al., 2010; Petrokofsky et al., 2015). Pericopsis elata (Harms) Meeuwen, a legume tree traded under the name Afrormosia or African teak, is a good example: its demand is strong on the international markets (Pérez et al., 2005; Doucet et al., 2016) and its natural regeneration is problematic under dense canopy (Bourland et al., 2012a). Having been completely overexploited in West Africa at the end of the $20^{\text {th }}$ century, $P$. elata has been listed on CITES Appendix II
Annotation \#17 (logs, sawn wood, veneer sheets, plywood and transformed wood) and is considered "endangered Alcd" by the IUCN (https://www. iucnredlist.org/species/33191/9759606). Nowadays, the main producing countries are DRC, Cameroon and the Republic of the Congo (Bourland et al., 2012b).

Natural populations of P. elata generally display Gaussian distribution of stem diameter, a characteristic of species with low natural regeneration (Bourland et al., 2012a; Ouédraogo et al., 2014; Vlam et al., 2014). This population structure does not guarantee the long-term availability of $P$. elata stems of exploitable diameter (Halpin \& Lorimer, 2017).

The introduction of the species in large-scale plantations may be a solution to compensate its overexploitation in Central Africa, at least if the wood conserves its good mechanical properties in plantations. Among various aspects, it requires to identify the optimal plantation density, hence to better understand how between tree interferences affect tree growth in both height and diameter. We expect that competition must impact growth. However, tree species usually react to light competition by investing more energy into height growth than diameter growth, which is interesting to obtain large stems (Brunner \& Nigh, 2000), so that maximal height growth may occur at an intermediate density. Genetic factors can also affect tree growth, so that the choice of seed trees can also matter when planning plantations (Sotelo et al., 2008). However, this aspect has rarely been investigated in hardwood tropical tree species, especially in Africa (Koskela et al., 2014).

The present study aims to determine the factors influencing the early growth rate of $P$. elata saplings under full light conditions and identify the density that optimizes the growth. More specifically, it addresses the following questions:

- at which density and level of interference with neighbouring plants do P. elata saplings maximize their growth in stem diameter and height? 
- how much of the variability in growth is explained by mother tree, indicating a genetic determinism?

\section{MATERIALS AND METHODS}

\subsection{Study location and environmental conditions}

The study took place in the Tshopo province, Democratic Republic of the Congo (DRC), near the city of Kisangani. Seeds were harvested in a 400 ha natural stand of P.elata located in Biaro forest $\left(25^{\circ} 20^{\prime} \mathrm{E}, 0^{\circ} 11^{\prime} \mathrm{N}\right), 30 \mathrm{~km}$ southeast of Kisangani. The experimental design (plantation) is located on the outskirts of the city of Kisangani $\left(25^{\circ} 15^{\prime} 58^{\prime \prime}\right.$ E, $0^{\circ} 30^{\prime}$ 42 " N, elevation $495 \mathrm{~m}$ ), in the concession of a logging company (Compagnie Forestière et de Transformation, CFT).

The climate of Kisangani is Af type according to the Köppen classification with an average annual temperature of $25^{\circ} \mathrm{C}$, a maximum temperature in February $\left(32{ }^{\circ} \mathrm{C}\right.$ ) and an average annual rainfall of 1,672 $\mathrm{mm}$ (De Ridder et al., 2014). The driest month has a precipitation of more than $60 \mathrm{~mm}$ and the thermal amplitude is less than $5{ }^{\circ} \mathrm{C}$ (Dudu, 1991). The region is characterized by a long rainy season from August to December, interrupted by two dry seasons in January-February and June-July and the mean relative atmospheric humidity is between 90\% and 95\% (De Ridder et al., 2014).

The Kisangani region is formed by recent superficial horizons and old ferralitic layers of soils rich in sand and clay (Mosango, 1983). The geological formation of the Biaro forest consists of sandstone, red clay, marl and limestone, with macro- and microporosity in the upper part of the soils (De Ridder et al., 2014). Fertility is low (cation exchange capacity - CEC - varies between 2 and 8 meq per $100 \mathrm{~g}$ ) and the soil is acidic (pH varies between 3.5 and 5.5) (De Ridder et al., 2014).

\subsection{Seed sampling and nursery}

Seeds were harvested between 17 September and 12 December 2016 in the 400 ha plot of Biaro forest, where all 196 P. elata trees (diameter at breast height $\geq 10 \mathrm{~cm}$ ) had been inventoried. Seed trees were retained only if they produced mature seeds and were sufficiently isolated to avoid any confusion of seed provenance (19 seed trees eventually contributed to the seed pool used). One week after harvesting, seeds were sowed in polyethylene bags containing soil with natural manure, and an ID label indicating the seed tree. The nursery was located next to the botanical garden of the Science Faculty campus of the University of Kisangani, under mild shading. After germination, we randomized the positions of the seedlings in the nursery and followed their growth for one year before transplantation.

\subsection{Transplantation following the Nelder design}

We installed three plantation trials in October 2017 according to the design Ia proposed by Nelder (1962), whereby plants are located along a set of concentric circles ensuring a gradient of sapling density (Figure 1). Each unit (Nelder 1, Nelder 2 and Nelder 3 ) is referred to as a replicate in the following sections. The experiment was carried out over an area of $135 \times 45=6,075 \mathrm{~m}^{2}$ (including areas around each Nelder design) and each replicate covers an area of $908 \mathrm{~m}^{2}$. This area was cleaned from former vegetation (fallow land), allowing to prevent the destruction of the designs by uncontrolled bush fires .

The replicates were placed next to each other to maximize the similarity of environmental conditions (edaphic, topographic and sun exposure). Each Nelder design consisted of 12 concentric circles, each one with 18 equally spaced saplings (Figure 1). The saplings located on the first and last circles formed the buffer zones, placed respectively at a distance of 0.6 and $15.6 \mathrm{~m}$ from the centre of the circles, so that a total of 180 saplings out of 216 were monitored for each replicate. The local spacing between neighbouring saplings ranged from $0.2 \times 0.2 \mathrm{~m}$ to $3.8 \times 3.8 \mathrm{~m}$ (Table 1).

The theoretical area $\mathrm{S}$ available for each sapling is related to the density of each circle:

$$
S=\frac{1}{18}\left\{\pi\left[l+\frac{(m-l)}{2}\right]^{2}-\pi\left[l-\frac{(l-k)}{2}\right]^{2}\right\}=\frac{\pi}{72}(m-k) \cdot(21+m+k)
$$

with $l$ the radius of the circle where the target sapling is located, $m$ the radius of the largest neighbouring circle, $k$ the radius of the smallest neighbouring circle and 18 the number of saplings per circle (Figure 2A).

Saplings from the nursery were transplanted on October 2017, when they had reached heights ranging from $40 \mathrm{~cm}$ to $160 \mathrm{~cm}$ (median around $65 \mathrm{~cm}$ ). As available sample sizes varied widely among maternal families, we could not conceive a well-balanced design. In Nelder 1 and Nelder 2, where 19 and 10 families were represented, we ensured that saplings from the same mother tree were never contiguous. This was not feasible in Nelder 3 , represented by seven families but with two of them constituting $88 \%$ of the saplings. Within each Nelder design, we ensured that represented families were well spread among the different circles to avoid any confounding effect between maternal tree and local density. Initial sapling height did not differ significantly among replicates. Dead saplings were replaced immediately when found. 


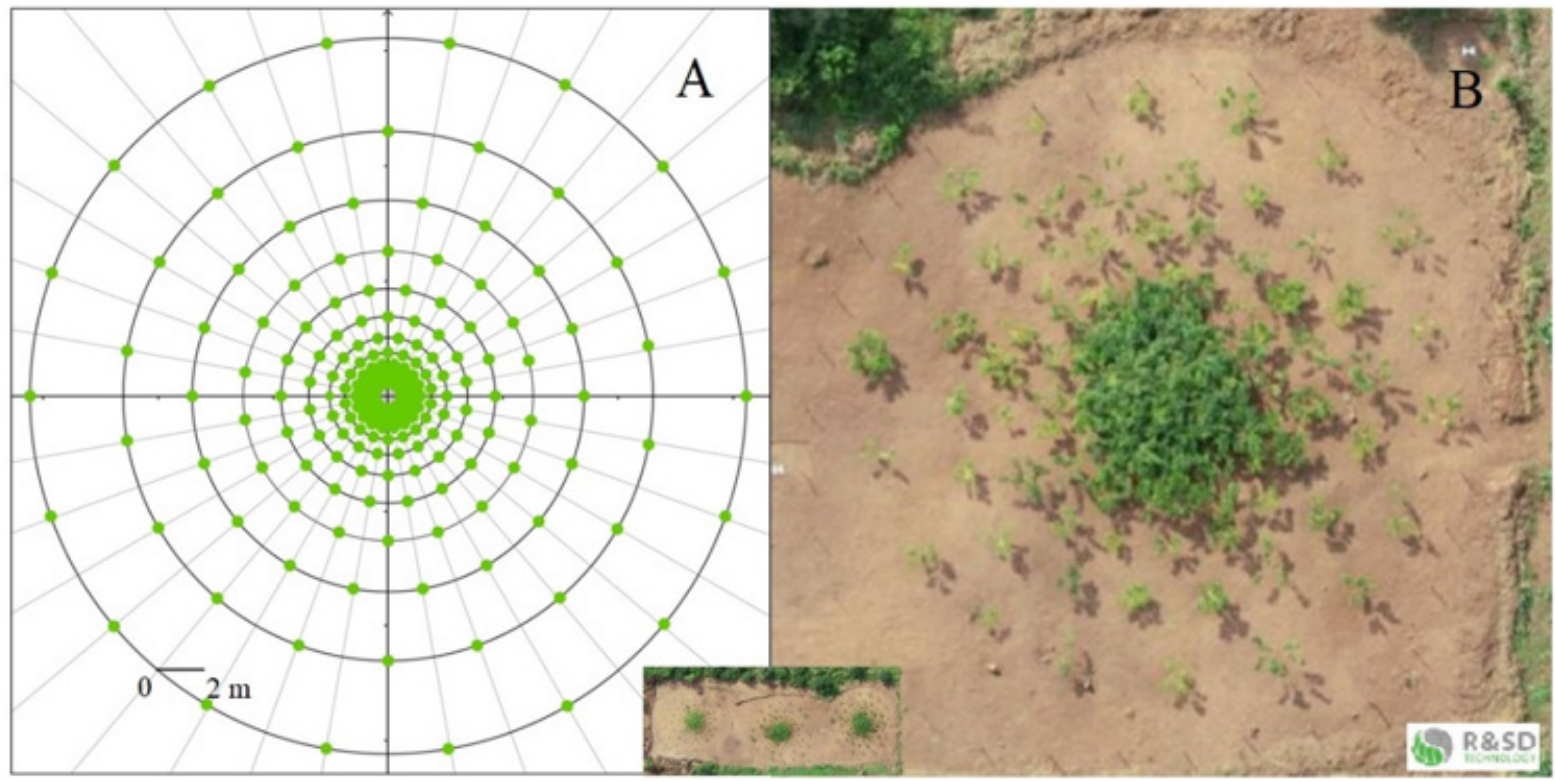

Figure 1. Plantation design following the spatial design of Nelder (1962), allowing to test the impact of contrasted densities on tree growth using a relatively small area. Saplings were planted at half of the intersections between a set of concentric circles and a set of 36 directions separated by an angle of $10^{\circ}$ (green points of panel A). The radii of two successive circles augmented by a ratio $\alpha=1.35$. Panel B: aerial view of one Nelder design, taken 16 months after transplantation, from an altitude of $100 \mathrm{~m}$ above ground level. The bottom inset shows an aerial view of the three replicates - Dispositif de la plantation suivant la conception spatiale de Nelder (1962), permettant de tester l'impact des densités contrastées sur la croissance des arbres en utilisant une surface relativement petite. Les plants ont été plantés aux intersections entre un ensemble de cercles concentriques et un ensemble de 36 directions séparées par un angle de $10^{\circ}$ (points verts du panneau A). Les rayons de deux cercles successifs augmentaient d'un rapport $\alpha=1,35$. Panneau $\boldsymbol{B}:$ vue aérienne d'un dispositif de Nelder, prise 16 mois après la transplantation, à une altitude de $100 \mathrm{~m}$ au-dessus du sol. L'encart du bas montre une vue aérienne des trois répétitions.

Table 1. Characteristics of the circles (C) along which saplings were planted in Nelder designs. The untested buffer circles are not shown - Caractéristiques des cercles $(C)$ le long desquels les plants ont été plantés dans les dispositifs de Nelder. Les cercles d'isolement n'étant pas testés ne sont pas indiqués.

\begin{tabular}{|c|c|c|c|c|c|c|c|c|c|c|}
\hline & C1 & $\mathrm{C} 2$ & C3 & $\mathrm{C} 4$ & C5 & C6 & C7 & C8 & C9 & $\mathrm{C10}$ \\
\hline Radius (m) & 0.77 & 1.03 & 1.40 & 1.89 & 2.55 & 3.45 & 4.66 & 6.30 & 8.52 & 11.50 \\
\hline $\begin{array}{l}\text { Area per plant } \\
\left(\mathrm{m}^{2}\right)\end{array}$ & 0.06 & 0.12 & 0.21 & 0.39 & 0.71 & 1.30 & 2.37 & 4.34 & 7.94 & 14.49 \\
\hline $\begin{array}{l}\text { Density } \\
\left(\text { stems }^{-1} \mathrm{ha}^{-1}\right)\end{array}$ & 158,751 & 86,044 & 46,613 & 25,794 & 14,079 & 7,702 & 4,219 & 2,304 & 1,260 & 690 \\
\hline Spacing (m) & $0.2 \times 0.2$ & $0.3 \times 0.3$ & $0.5 \times 0.5$ & $0.6 \times 0.6$ & $0.8 \times 0.8$ & $1.0 \times 1.0$ & $1.5 \times 1.5$ & $2.1 \times 2.1$ & $2.8 \times 2.8$ & $3.8 \times 3.8$ \\
\hline
\end{tabular}

\subsection{Data collection and analyses}

The total height and diameter at $10 \mathrm{~cm}$ from the collar were measured after two months and then at three months intervals on all saplings between December 2017 and June 2019, using a ruler and a calliper graduated in $\mathrm{cm}$ and $\mathrm{mm}$, respectively. The total height was measured from the collar to the terminal bud of the longest branch. Weeding was carried out before each measurement period.

To avoid a bias resulting from the stress experienced during transplantation, which could slow down initial growth, the growth rates in diameter and height were measured by the increments that occurred between the $5^{\text {th }}$ and $20^{\text {th }}$ month after transplantation, multiplied by $12 / 15$ to obtain annual growth rates. Saplings replaced $(2.8 \%)$ as a result of mortality caused by vandalism or planting stress were not included in the statistical growth analyses.

The degree of interference between neighbouring saplings is expected to decay from circle $\mathrm{C} 1$ to $\mathrm{C} 12$ as the spacing between plants increases (Table 1) but it should also depend on the respective sizes of adjacent plants. To take this into account, we computed a 


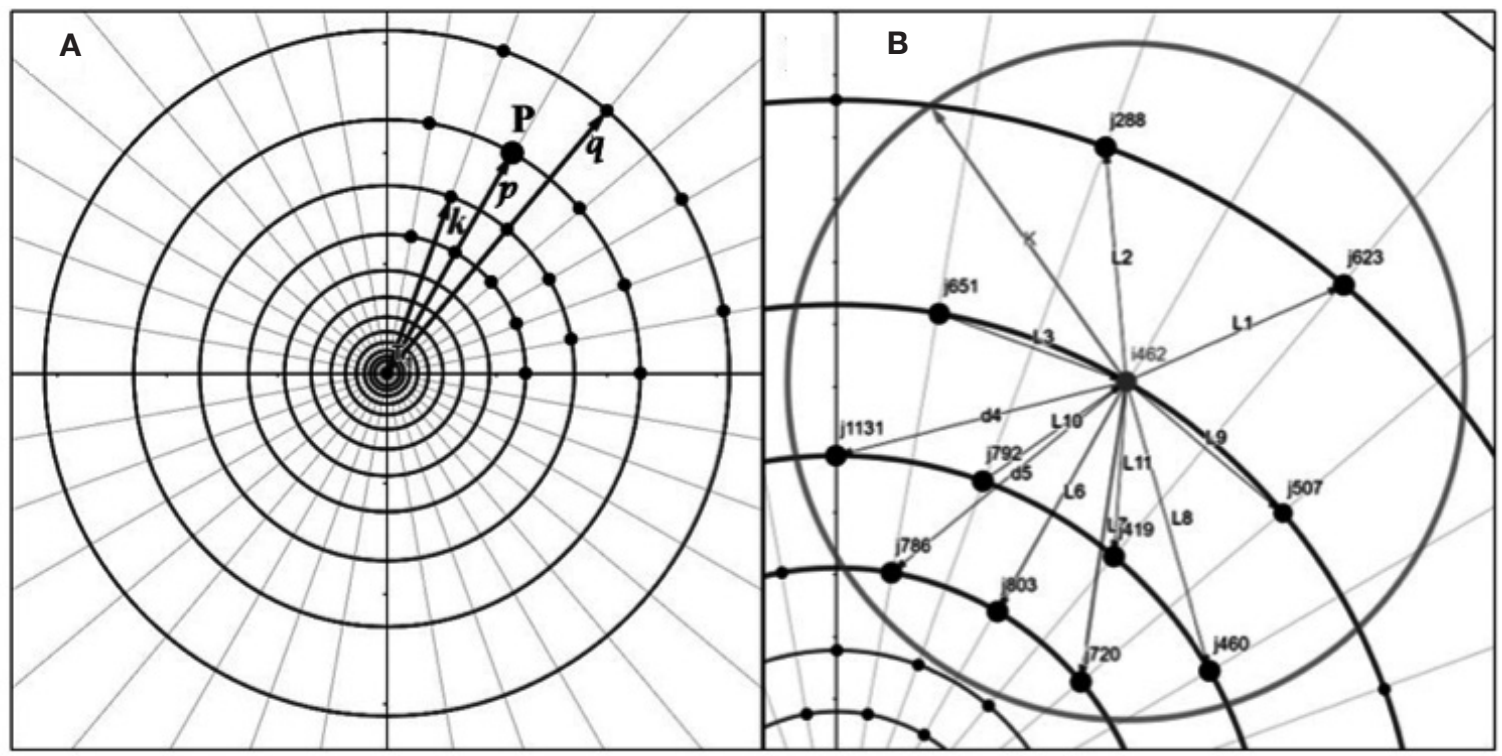

Figure 2. Spacing available per sapling and competition in Nelder designs. In $\mathbf{A}$, the radii of the circles for the calculation of the area S available for each sapling (equation 1). In $\mathbf{B}$, illustration of the Hegyi (1974) Competition Index: the circle, of radius $\mathrm{K}$, delimits the competition area for sapling i462. $\mathrm{L}$ is the distance between $\mathrm{i} 462$ and its competitors ( $j$ individuals). The values of K were $2.7 \mathrm{~m}, 2.4 \mathrm{~m}$ and $1.9 \mathrm{~m}$, for Nelder 1, Nelder 2 and Nelder 3, respectively - Espace disponible par plant et compétition dans les dispositifs de Nelder. En A, les rayons des cercles pour le calcul de la surface $S$ disponible pour chaque plant (équation 1). En B, illustration de l'indice de compétition de Hegyi (1974) : le cercle, de rayon K, délimite la surface de compétition pour le plant i462. L est la distance entre i462 et ses compétiteurs ( $\mathrm{j}$ individus). Les valeurs de K étaient de 2,7 m ; 2,4 m et 1,9 m; pour Nelder 1, Nelder 2 et Nelder 3, respectivement.

competition index $\left(\mathrm{CI}_{i}\right)$ for each sapling $i$ as a function of the distance and diameter of neighbouring saplings situated within a circle of radius $\mathrm{K}$ (Figure 2B), according to the relationship (Hegyi, 1974; Vanclay et al., 2013):

$$
\mathrm{CI}_{i}=\sum_{\substack{j=1 \\ j \neq i}}^{n}\left(\frac{\mathrm{D}_{j}}{\mathrm{D}_{i} \mathrm{~L}_{i j}}\right)
$$

where $\mathrm{D}_{i}$ and $\mathrm{D}_{j}$ are the respective diameters of the sapling subject $i$ and competitor $j$ and $\mathrm{L}_{i j}$ is the distance between $i$ and $j\left(\mathrm{~L}_{i j} \leq \mathrm{K}\right)$. The competition radius $\mathrm{K}$, which is the maximal distance at which we consider that saplings can interfere, was calculated as the mean height of all the saplings of a given replicate, reaching $2.7 \mathrm{~m}, 2.4 \mathrm{~m}$ and $1.9 \mathrm{~m}$, for Nelder 1,2 and 3, respectively (Uhl et al., 2015; Figure 2B).

The medians of the diameter and height annual growth rates were compared between replicates using Kruskal-Wallis tests. The coefficient of variation (CV) was used to calculate the variability between circles. We modelled growth rates with generalized additive models (GAM) of the Gaussian type (Zuur et al., 2009). These models combine linear and non-linear explanatory variables influencing the response variable (Uhl et al., 2015).
The models used are of the form:

$$
\begin{aligned}
& \Delta \mathrm{H}_{q p i}=a_{q}+b \cdot \mathrm{InH}_{i}+f\left(\mathrm{CI}_{i}\right)+\alpha_{p}+\varepsilon_{i} \\
& \Delta \mathrm{D}_{q p i}=a_{q}+b \cdot \mathrm{InD}_{i}+f\left(\mathrm{CI}_{i}\right)+\alpha_{p}+\varepsilon_{\mathrm{i}} \\
& \text { with } \alpha_{p} \sim \mathrm{N}\left(0, d^{2}\right) \text { and } \varepsilon_{i} \sim \mathrm{N}\left(0, \sigma^{2}\right)
\end{aligned}
$$

where $\Delta \mathrm{H}_{q p i}$ and $\Delta \mathrm{D}_{q p i}$ are the response variables, respectively the annual increments in height and diameter in a Nelder design $q$ for sapling $i$ from a mother tree $p, a_{q}$ is the effect of the design (fixed effect), $b$ the slope describing the impact of the initial height $\left(\mathrm{InH}_{i}\right)$ or initial diameter $\left(\mathrm{InD}_{i}\right)$ of the sapling (at the $5^{\text {th }}$ month after transplantation), $f\left(\mathrm{CI}_{i}\right)$ is a nonparametric smoothing function describing the influence of the competition index on sapling $i$, $\alpha_{p}$ is the mother tree effect (random effect following a centred normal distribution of standard deviation $d$ ) and $\varepsilon_{i}$ is the residual error of the model (centred normal distribution of standard deviation $\sigma$ ). We estimated the $\mathrm{CV}$ expressing the relative effect of the mother trees by the ratio of $d$ over the mean growth rate, where $d$ is estimated by the GAM. To assess if the individualbased competition index $\left(\mathrm{CI}_{i}\right)$ better explains growth rates than a more simple model accounting only from 
the local sapling density, we also ran models similar to (3) and (4) but replacing $f\left(\mathrm{CI}_{i}\right)$ by $f\left(\mathrm{CN}_{i}\right)$, where $\mathrm{CN}_{i}$ denotes the circle number (1 to 12) where sapling $i$ is located.

Mother trees represented by $<10$ individuals (seven out of 19 mother trees) were not included in the models, removing only $4 \%$ of the saplings. To find the optimal model, an iterative approach consisting of adding or removing each explanatory variable in turn was used. The best models were selected on the basis of the Akaike Information Criterion (AIC). The ' $m g c v$ ' package version 1.8-28 (Wood, 2011) for the statistical software R (R Core Team, 2018) was used for the GAM. The distances between saplings were computed with the GeoGebra Classique software.

\section{RESULTS}

\subsection{Height and diameter growth trajectories}

Sapling height and diameter varied with time and densities and showed weak growth rates during the first five months after transplantation (Figure 3). Growth rates seemed fairly constant between the $8^{\text {th }}$ and $17^{\text {th }}$ month, but tended to be lower between March and June, both in 2018 and 2019 (Figure 3). At 20 months, sapling height ranged from 24 to $451 \mathrm{~cm}$, with a mean and standard deviation of $152.7 \pm 82.8 \mathrm{~cm}(\mathrm{CV}=$ $54.2 \%$ ), while the diameter ranged from 3 to $72 \mathrm{~mm}$, with a mean and standard deviation of $19.2 \pm 11.1 \mathrm{~mm}$ $(\mathrm{CV}=57.6 \%)$.

\subsection{Competition Index (CI)}

The competition index averaged $37.6 \mathrm{~m}^{-1}$ with a standard deviation of $49.1 \mathrm{~m}^{-1}$. Differences between replicates were not significant (Kruskal-Wallis; $X^{2}=$ 2.14; $p=0.34)$. The CI was highest on circle C1 (128.7 \pm $63.9 \mathrm{~m}^{-1}$ ) and decreased accordingly to circle density, reaching zero for the last circle $\mathrm{C} 10$ (Figure 4A). The competition index varied also significantly within each circle (except for $\mathrm{C} 10$ ) with a $\mathrm{CV}$ ranging between $21 \%$ and $50 \%$.

\subsection{Annual height increment}

The overall annual height increment was $136.5 \pm$ $48.7 \mathrm{~cm} \cdot$ year $^{-1}$. It was largest in Nelder 1 (152.9 \pm $48.1 \mathrm{~cm} \cdot$ year $\left.^{-1}\right)$ followed by Nelder $2(132.4 \pm 49.0 \mathrm{~cm}$. year $^{-1}$ ) and then Nelder 3 (124.2 $\pm 44.4 \mathrm{~cm} \cdot$ year $\left.^{-1}\right)$. These differences were significant (Kruskal-Wallis; $\left.X^{2}=35.35 ; p=2.11 \cdot 10^{-8}\right)$. It increased from circle $\mathrm{C} 1$ to $\mathrm{C} 3$ or $\mathrm{C} 4$ and then decreased towards $\mathrm{C} 10$ (Figure 4B).

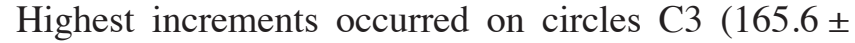
$39.2 \mathrm{~cm} \cdot$ year $\left.^{-1}\right), \mathrm{C} 4\left(164.2 \pm 42.0 \mathrm{~cm} \cdot\right.$ year $\left.^{-1}\right)$ and C5 $\left(156.6 \pm 39.8 \mathrm{~cm} \cdot\right.$ year $\left.^{-1}\right)$. Variability was high within all Nelder circles (CV between 19 and 47\%).

The GAM explained $40 \%$ of the deviance in sapling height increment, and leads to residuals showing satisfactory distribution (Appendix Figure A1). Annual height increment significantly depended on competition $\left(p<2 \cdot 10^{-16}\right)$, showing a non-linear and non-monotonic relationship (Table 2). It peaked when the competition index was close to $50 \mathrm{~m}^{-1}$ (Figure 5A).
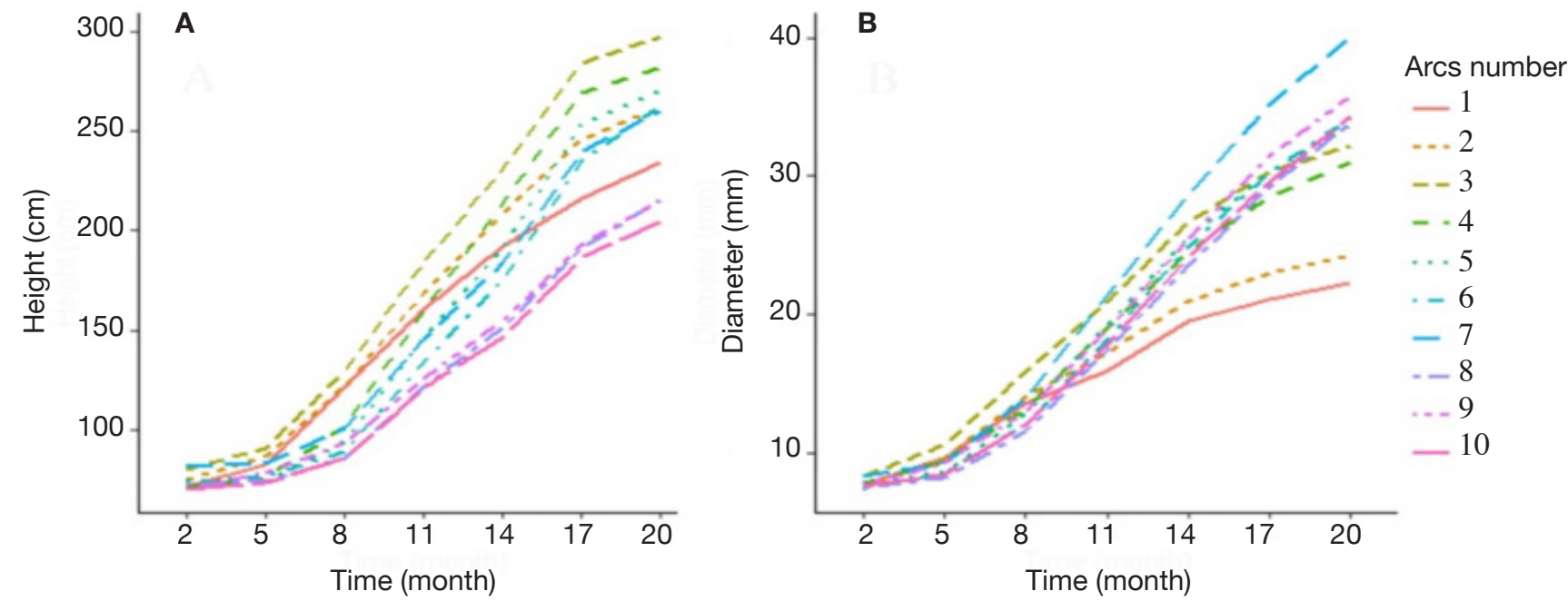

Figure 3. Mean sapling height (A) and diameter (B) as a function of time and experimental densities (circle of Nelder designs) - Hauteur $(\boldsymbol{A})$ et diamètre $(\boldsymbol{B})$ moyens des plants en fonction du temps et des densités expérimentales (cercle du dispositif de Nelder).

Values were averaged over the three Nelder designs - les valeurs ont été moyennées sur les trois dispositifs de Nelder. 

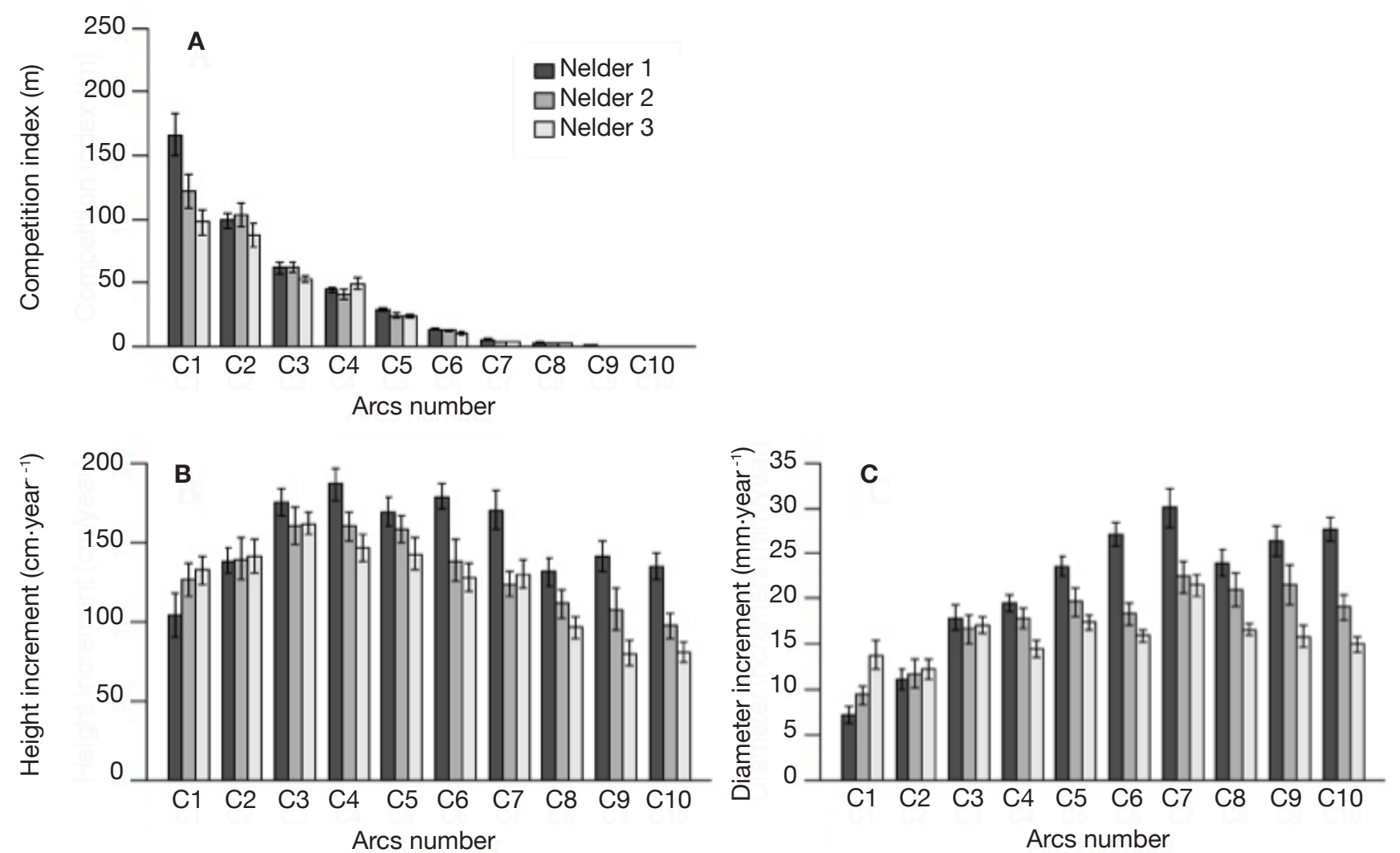

Figure 4. Variation in the competition index $(\mathbf{A})$, annual height $(\mathbf{B})$ and diameter $(\mathbf{C})$ increments of saplings along the circles of the Nelder designs - Variation de l'indice de compétition $(\boldsymbol{A})$, accroissements annuels en hauteur $(\boldsymbol{B})$ et en diamètre $(\boldsymbol{C})$ des plants le long des cercles dans les dispositifs de Nelder.

Error bars represent standard errors of the mean values - les barres d'erreur représentent les erreurs types des valeurs moyennes.

Height increment was also significantly influenced by sapling mother trees $\left(p=7.56 \cdot 10^{-16}\right)$, with a standard deviation of annual increment of $10.4 \mathrm{~cm}$. year $^{-1}$ (Table 2). Hence, reported to the mean annual increment, the variation due to mother trees reached a coefficient of variation of $\mathrm{CV}=10.4 / 136.5=7.6 \%$. The GAM confirmed that height increment significantly differed among Nelder replicates (Table 2), while the initial height had no significant impact and was removed from the final model. When we used the circle number instead of the local competition index to run the model, the explained variance dropped from $\mathrm{R}^{2}=40.2 \%$ to $33.0 \%$ and the AIC increased by 53 units $(5,276$ to 5,329$)$.

\subsection{Annual diameter increment}

The overall annual diameter increment was $18.4 \pm$ $7.7 \mathrm{~mm} \cdot$ year $^{-1}$. The largest mean was observed in Nelder $1\left(21.4 \pm 9.1 \mathrm{~mm} \cdot \mathrm{year}^{-1}\right)$ followed by Nelder 2 $\left(17.8 \pm 7.6 \mathrm{~mm} \cdot\right.$ year $\left.^{-1}\right)$ and then Nelder 3 (16.0 \pm $4.8 \mathrm{~mm} \cdot$ year $\left.^{-1}\right)$. These differences were significant
(Kruskal-Wallis; $X^{2}=43.21 ; p=4.15 \cdot 10^{-10}$ ). The increments tended to increase from circle $\mathrm{C} 1$ to $\mathrm{C} 7$ and then to decrease until C10 (Figure 4C). High averages were located on C5 $\left(20.2 \pm 5.8 \mathrm{~mm} \cdot \mathrm{year}^{-1}\right)$, C6 $\left(20.5 \pm 6.7 \mathrm{~mm} \cdot\right.$ year $\left.^{-1}\right)$, C7 $\left(24.6 \pm 8.3 \mathrm{~mm} \cdot\right.$ year $\left.^{-1}\right)$ and C8 $\left(20.5 \pm 6.7 \mathrm{~mm} \cdot\right.$ year $\left.^{-1}\right)$. Variability was high within all circles (CV between 22 and $50 \%$ ).

The GAM explained $56 \%$ of the deviance in annual diameter increment (residuals shown in Appendix Figure A2). Diameter increment decreased nonlinearly but monotically with the competition index $\left(p<2 \cdot 10^{-16}\right.$; Table 2; Figure 5B). It also depended on the initial diameter $\left(p=1.38 \cdot 10^{-12}\right)$ and varied significantly among Nelder designs (Table 2). Finally, it was also significantly influenced by the mother trees of the saplings $\left(p=6.73 \cdot 10^{-5}\right.$; estimated standard deviation among maternal families reaching $1.2 \mathrm{~mm} \cdot$ year $^{-1}, \mathrm{CV}=6.4 \%$; Table 2). Using the circle number instead of the local competition index, the explained variance dropped from $\mathrm{R}^{2}=56.1 \%$ to $50.5 \%$ and the AIC increased by 64 units $(3,197$ to $3,261)$. 


\section{DISCUSSION}

Our results highlight that the density at planting (competition) and the genetic origin (i.e. mother tree) of the saplings influence their growth. For both height and diameter growth, our results show that the competition index $(\mathrm{CI})$, which accounts of the relative heights of the neighbouring plants, better explains the growth rate than the circle number, which reflects only the local density of saplings. The impact of density or competition on growth rates is far from linear and shows a mode in the case of height growth (Figures 4 and 5), justifying the use of a smoothing function (GAM) to describe it. Hereafter, we discuss the different effects observed.

\subsection{Determinants of saplings height growth}

Density seems at this stage of the evolution of the plantation to stimulate height growth of P. elata saplings, with an optimum corresponding to a spacing of c. $0.5-0.6 \mathrm{~m}$ between saplings (Figure 4; Table 1). Similar observations were reported by Fayolle et al. (2015) when comparing the performance of non-competitive and competitive stems.

The mean height increment $(135.3 \pm 50.1 \mathrm{~cm}$. year $^{-1}$ ) was greater than that found by Ouédraogo et al. (2014) in Cameroon (80.32 $\pm 36.05 \mathrm{~cm} \cdot$ year $\left.^{-1}\right)$ in logging gaps, probably due to higher sun exposure. At the densities with the highest increments, there was a high variability in the competition index.

The competition for access to light would have favoured the scrolling of saplings (Brunner \& Nigh, 2000; Ngueguim et al., 2012; Parrott et al., 2012; Kuehne et al., 2013; Fayolle et al., 2015), explaining why size is negatively correlated with the competition index until some density threshold (Vanclay et al., 2013; Uhl et al., 2015). Above 46,000 stems $\cdot$ ha $^{-1}$, competition no longer favours height growth but impedes it. This is in line with the observations of Gourlet-Fleury (1998) showing that dominated trees do not develop their crowns sufficiently, with the result that their growth is limited. It is likely that the optimal density maximizing height growth rate will move toward lower densities as trees age and increasingly compete for resources. Therefore, the optimal density at 20 months should not be considered as an optimal operational density for P. elata plantations.

The growth rate was larger in Nelder 1 than Nelder 2 or 3 . Whether subtle differences of soil fertility between the three Nelder plots might explain these differences remains to be investigated. By contrast, the initial height did not influence the growth of $P$. elata saplings. 

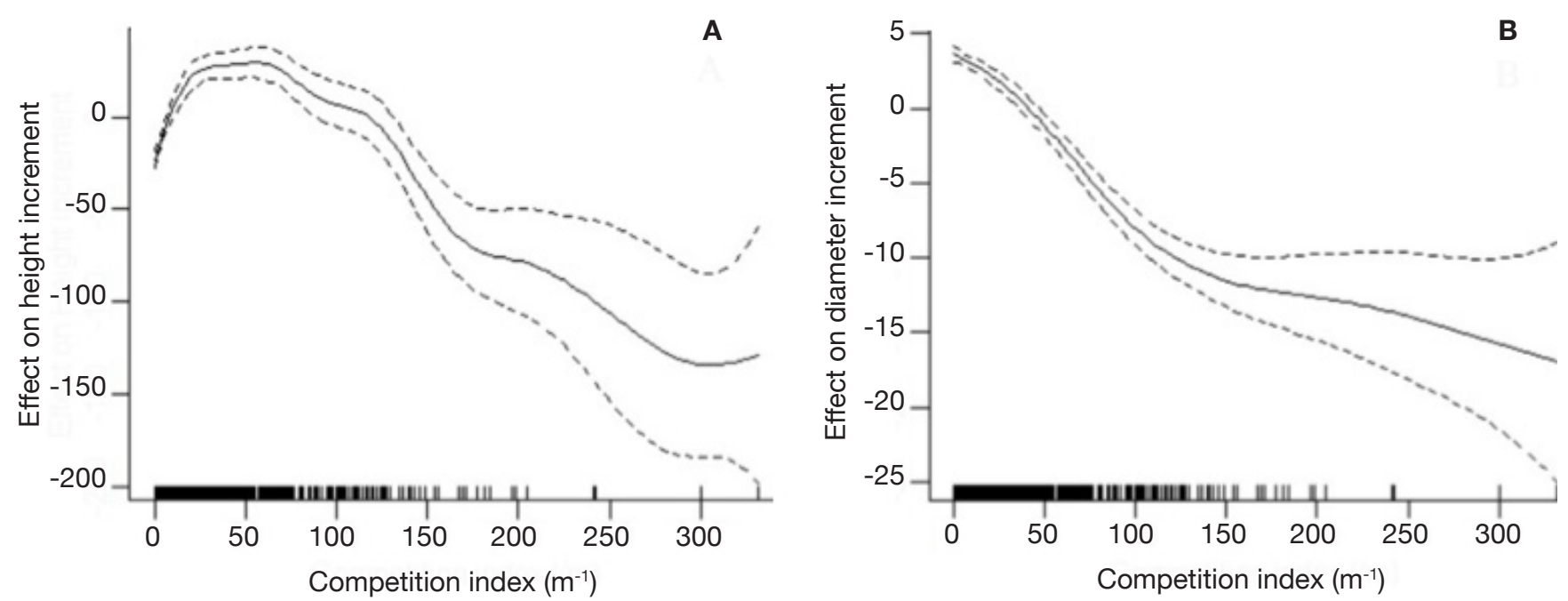

Figure 5. Effect of competition on annual height (A) and diameter (B) increments - Effet de la compétition sur les accroissements annuels en hauteur $(A)$ et en diamètre $(B)$.

Y-axes, the spline functions modelling the effect of the competition index on the increments measured between the $5^{\text {th }}$ and $20^{\text {th }}$ month. The area between the dotted lines represents the $95 \%$ confidence interval. The vertical lines on the X-axes represent the number of observations - Axes $Y$, les fonctions spline modélisant l'effet de l'indice de compétition sur les accroissements mesurés entre le $5^{e}$ et le $20^{e}$ mois. L'aire entre les lignes en pointillés représente l'intervalle de confiance à $95 \%$. Les lignes verticales sur les axes X représentent le nombre d'observations.

\subsection{Determinants of saplings diameter growth}

The mean diameter increment $\left(18.4 \pm 7.7 \mathrm{~mm} \cdot \mathrm{year}^{-1}\right)$ found in this study is larger than the values reported in Cameroonian logging gaps under silvicultural treatments (clearings) at 60 months $(9.1 \pm 4.6 \mathrm{~mm}$. year ${ }^{-1}$ in Fayolle et al., 2015; $8.0 \pm 4.0 \mathrm{~mm} \cdot$ year $^{-1}$ in Ouédraogo et al., 2014). The latter studies occurred in the concession of Pallisco Company, certified FSC (Forest Stewardship Council), which practices controlled felling. Under these conditions, the average size of the gaps is relatively small, which severely limits the amount of sunshine for the saplings (including gaps that have been completely cleared). Hence, difference of light exposure might explain these differences in diameter growth.

As for height growth, diameter growth varied among Nelder plots, was significantly influenced by the mother tree, and strongly responded to sapling density (competition). However, unlike height growth, diameter growth was positively affected by the initial diameter of the saplings after transplantation, and it increased monotonically as competition decreased. Thus, saplings grow faster in diameter at lower densities (Lemoine \& Sartolou, 1980; Kuehne et al., 2013; Uhl et al., 2015). In addition, local environmental conditions influenced by the transport and use of water and nutrients by saplings, are likely to influence their development (Beckage \& Clark, 2003; Rio et al., 2014; Colombaroli et al., 2016; Kearsley et al., 2017).
In future analyses, it may be appropriate to integrate the environmental changes that occur as the seedlings grow, for example due to the faster accumulation of litter in the centre of repetitions, compared to their extremities.

\subsection{Influence of mother tree on growth}

Our results corroborate the few studies conducted on tropical hardwood species showing that a significant part of the variability in tree growth can be explained by genetic factors (e.g., León et al., 2017; Luechanimitchit et al., 2017; Sawitri et al., 2020), a prerequisite for tree breeding. Kuehne et al. (2013) found that the influence of the mother tree on growth is most noticeable during the juvenile stages. This is the well-known "early selection" principle applied by forest geneticists right from the nursery (Nanson, 2004). We used openpollinated seeds but as P. elata is able to self-fertilize (D.-M. Assumani \& O.J. Hardy, unpublished), we could not estimate the heritability of growth rates by simply assuming that we had half-sib families. Saplings will need to be genotyped using genetic markers to assess their actual relatedness and to estimate the heritability of measured traits. Among the genetic causes influencing growth, inbreeding depression may also be an important factor in species endogamous like P. elata. It results from the expression of deleterious recessive genes in homozygotes, diminishing the fitness of the more consanguineous individuals (Hedrick 
et al., 2015). The vast majority of tropical trees have developed mechanisms preventing or strongly limiting inbreeding (e.g., self-incompatibility system) but P. elata is an exception (Micheneau et al., 2011). Hence, by identifying self-fertilized saplings using genetic markers, our plantation trials will also allow us to assess whether inbreeding depression is a feature to take into account.

\subsection{Study improvement options}

Knowledge of the growth dynamics of saplings can lead to better management of stands rich in P. elata stems, in plantations or in natural forests where $P$. elata is very gregarious. Our results are based on seedlings aged about 30 months ( 7 to 10 months in the nursery plus 20 months of planting) and we need to wait a few more years before being able to make robust recommendations regarding optimal tree spacing for plantations. Moreover, studying the influence of environmental conditions (climatic, topographic, etc.) for the development of P. elata could be relevant (Addo-Danso et al., 2012). Nevertheless, our preliminary results show the interest of trials based on Nelder design, which are also appropriate to assess the performances of different seed families.

\section{CONCLUSIONS}

Our study of the growth dynamics of P. elata saplings allows us to assess the optimal plantation density (i.e. best increments in both height and diameter). Density had a non-linear relationship with diameter and height growth. As expected, the sapling density that maximizes the increment in height is larger than the one maximizing the increment in diameter. At 20 months, the best compromise is found at the C5 arc corresponding to some 14,079 stems $\cdot \mathrm{ha}^{-1}$, leading to mean increments of $157 \pm 40 \mathrm{~cm} \cdot$ year $^{-1}$ in height and $20 \pm 6 \mathrm{~mm} \cdot \mathrm{year}^{-1}$ in diameter. Pericopsis elata could therefore be planted at a spacing of $0.8 \times 0.8 \mathrm{~m}$ to promote sapling growth in the first 20 months. However, this optimal density will need to be re-evaluated on longer term. The genetic origin of the saplings influenced the increments in height and diameter, indicating that selection of plus seed trees should be efficient. On longer term, the design will make it possible to assess the impact of inbreeding on the growth of saplings. Our plantation trials based on Nelder design prove interesting to assess the effects of both the density and the seed tree on tree growth. Such design, requiring a limited surface, could be replicated in other areas and for other commercial species that may be of interest for restoring forest landscapes.

\section{Acknowledgements}

We are grateful to the "FOrmation, Recherche, Environnement dans la TShopo" (FORETS) project for financially supporting the first author during his studies. This project, funded with resources from the XI European Development Fund, is led by CIFOR in partnership with the company Resources and Synergies Development (R\&SD) and the University of Kisangani. Our thanks also go to the Belgian Directorate-general Development Cooperation and Humanitarian Aid funded project N3-GeForCo led by the Royal Museum for Central Africa, at the origin of the experiment, as well as the ARES "Projets de synergie-2020/ Régénération assistée de Pericopsis elata (Harms) Meeuwen : étude par une approche de traits fonctionnels foliaires" grant. We thank the company R\&SD DRC, through its Manager G. Assimbo, for logistical assistance and the company "Compagnie Forestière et de Transformation" (CFT) through its Director K. Ammacha, for hosting the tree nursery and the Nelder wheels, providing unlimited access to the site and other logistical assistance. We are grateful to C. Lubwilu Lolo, P. Mayele Maloko, E. Ngombo Luzolo (CFT) and E. Tudico and his team (R\&SD Construction sia) for technical assistance on the field. O.H. is supported by a Belgian Fund for Scientific Research, F.R.S-FNRS.

\section{Authors Contributions}

N.B. and H.B. conceived and implemented the Nelder designs. D-M.A. collected the seeds in the Biaro forest, set up and monitored the saplings in the nursery under N.B. and O.H.'s supervision. H.H. and N.B. led plantation works. H.H. and C.I. collected data on the field and at the laboratory. C.I., O.H. and G.L. performed the statistical analyses. C.I. wrote the manuscript with the support of N.B., O.H., G.L., L.N. and H.B. The final version of the manuscript was read and corrected by all the authors.

\section{Bibliography}

Addo-Danso S. et al., 2012. Survival and growth of Nauclea diderrichii and Pericopsis elata in monoculture and mixed-species plots in Ghana. J. Trop. Ecol., 24(1), 3745.

Beckage B. \& Clark J.S., 2003. Seedling survival and growth of three forest tree species: the role of spacial heterogeneity. Ecology, 84(7), 1849-1861, doi. org/10.1890/0012-9658(2003)084[1849:SSAGOT]2.0. $\mathrm{CO} ; 2$

Bourbier L. et al., 2013. Large-scale estimation of forest canopy opening using remote sensing in Central Africa. Bois For. Trop., 315(1), 3-9.

Bourland N. et al., 2012a. Ecology of Pericopsis elata (Fabaceae), an endangered timber species in Southeastern Cameroon. Biotropica, 44(6), 840-847, doi.org/10.1111/ j.1744-7429.2012.00874.x 
Bourland N. et al., 2012b. Ecology and management of Pericopsis elata (Harms) Meeuwen (Fabaceae) populations: a review. Biotechnol. Agron. Soc. Environ, 16(4), 486-498.

Brunner A. \& Nigh G., 2000. Light absorption and bole volume growth of individual douglas-fir trees. Tree Physiol., 20(5-6), 323-332, doi.org/10.1093/ treephys/20.5-6.323

Colombaroli D. et al., 2016. Stable carbon and oxygen isotopes in tree rings show physiological responses of Pericopsis elata to precipitation in the Congo Basin. J. Trop. Ecol., 32(3), 213-225, doi.org/10.1017/ S0266467416000134

De Ridder M. et al., 2014. Dendrochronological potential in a semi-deciduous rainforest: the case of Pericopsis elata in Central Africa. Forests, 5(12), 3087-3106, doi. org/10.3390/f5123087

Doucet J.L. et al., 2016. Enrichment of Central African logged forests with high-value tree species: testing a new approach to regenerating degraded forests. Int. J. Biodivers. Sci. Ecosyst. Serv. Manage., 12(1), 83-95, doi.org/10.1080/21513732.2016.1168868

Dudu A., 1991. Étude du peuplement d'insectivores et de rongeurs de la forêt ombrophile de basse altitude du Zaïre (Kisangani, Masako). Thèse de doctorat: Universiteit Antwerpen (Belgique).

Fayolle A. et al., 2015. Differential performance between two timber species in forest logging gaps and in plantations in Central Africa. Forests, 6(2), 380-394, doi.org/10.3390/f6020380

Fétéké F. et al., 2015. Modéliser la croissance de quatre essences pour améliorer la gestion forestière au Cameroun. Bois For. Trop., 325(3), 5-20, doi. org/10.19182/bft2015.325.a31269

Gond V. et al., 2013. Vegetation structure and greenness in Central Africa from Modis multi-temporal data. Phil. Trans. R. Soc., 368(1625), 1-8, doi.org/10.1098/ rstb.2012.0309

Gourlet-Fleury S., 1998. Indices de compétition en forêt dense tropicale humide : étude de cas sur le dispositif sylvicole expérimental de Paracou (Guyane française). Ann. For. Sci., 55(6), 623-654, doi.org/10.1051/ forest: 19980601

Halpin C.R. \& Lorimer C.G., 2017. A demographic approach to evaluating tree population sustainability. Forests, 8(46), 1-26, doi.org/10.3390/f8020046

Hedrick P.W., Hellsten U. \& Grattapaglia D., 2015. Examining the cause of high inbreeding depression: analysis of whole-genome sequence data in 28 selfed progeny of Eucalyptus grandis. New Phytol., 209, 600611, doi.org/10.1111/nph.13639

Hegyi F., 1974. A simulation model for managing Jackpine stands. In: Fries J., ed. Growth models for tree and stand simulation. Research Note No. 30. Stockholm: Royal College of Forestry, Department of Forest Yield Research, 74-90.
Kearsley E. et al., 2017. Functional community structure of African monodominant Gilbertiodendron dewevrei forest influenced by local environmental filtering. Ecol. Evol., 7(1), 295-304, doi.org/10.1002/ece3.2589

Koskela J. et al., 2014. Utilization and transfer of forest genetic resources: a global review. For. Ecol. Manage., 333, 22-34, doi.org/10.1016/j.foreco.2014.07.017

Kuehne C., Kublin E., Pyttel P. \& Bauhus J., 2013. Growth and form of Quercus robur and Fraxinus excelsior respond distinctly different to initial growing space: results from 24-year-old Nelder experiments. J. For. Res., 24(1), 1-14, doi.org/10.1007/s11676-013-0320-6

Lemoine B. \& Sartolou A., 1980. Densité de peuplement, concurrence et coopération chez le pin maritime. Ann. Sci. For., 37(3), 217-237.

León N. et al., 2017. Expected genetic gain and genotype by environment interaction in almond (Dipteryx panamensis (Pittier) Rec. and Mell) in Costa Rica. Silvae Genet., 66(1), 9-13, doi.org/10.1515/sg-20170002

Ligot G. et al., 2019. Growth determinants of timber species Triplochiton scleroxylon and implications for forest management in Central Africa. For. Ecol. Manage., 437, 211-221, doi.org/10.1016/j.foreco.2019.01.042

Luechanimitchit P. et al., 2017. Genetic parameter estimates for growth, stem-form and branching traits of Casuarina junghuhniana clones grown in Thailand. For. Ecol. Manage., 404, 251-257, doi.org/10.1016/j. foreco.2017.08.030

Makana J.R. et al., 2011. Demography and biomass change in monodominant and mixed old-growth forest of the Congo. J. Trop. Ecol., 27(5), 447-461, doi.org/10.1017/ S0266467411000265

Micheneau C.etal.,2011. Development and characterization of microsatellite loci in Pericopsis elata (Fabaceae) using a cost-efficient approach. Am. J. Bot., 98(10), e268-e270, doi.org/10.3732/ajb.1100070

Mosango M., 1983. Une estimation du niveau d'accumulation des diaspores dans les sols des groupements herbacés à Portulaca quadrifida L. et à Talinum triangulare (Jacq.) Willd. à Kisangani (Zaïre). Bull. Soc. R. Bot. Belg., 116(1), 55-61.

Nanson A., 2004. Génétique et amélioration des arbres forestiers. Gembloux, Belgique: Les Presses agronomiques de Gembloux.

Nelder J.A., 1962. New kinds of systematic devices for spacing experiments. Biometrics, 18(3), 283-307, doi: $10.2307 / 2527473$

Ngueguim J.R. et al., 2010. Diversité floristique sous canopée en plantation forestière de Mangombe-Edea (Cameroun). Biotechnol. Agron. Soc. Environ., 14(1), 167-176.

Ngueguim J.R. et al., 2012. Growth and productivity of Pericopsis elata (Harms) Meeuwen in some forest plantations of Cameroon. For. Sci. Technol., 8(1), 1-10, doi.org/10.1080/21580103.2012.658234 
Obiang N.L.E. et al., 2010. Spatial pattern of Central African rainforests can be predicted from average tree size. Oikos, 119(10), 1643-1653, doi.org/10.1111/j.16000706.2010.18440.x

Ouédraogo D.Y. et al., 2014. Enrichment of logging gaps with a high conservation value species (Pericopsis elata) in Central African moist forest. Forests, 5(12), 30313047, doi.org/10.3390/f5123031

Parrott D.L., Joshua S.B. \& Lhotka J.M., 2012. Designing Nelder wheel plots for tree density experiments. New For., 43, 245-254, doi.org/10.1007/s11056-011-9278-4

Pérez R.M. et al., 2005. Logging in the Congo Basin: a multi-country characterization of timber companies. For. Ecol. Manage., 214, 221-236, doi.org/10.1016/j. foreco.2005.04.020

Petrokofsky G. et al., 2015. Comparative effectiveness of silvicultural interventions for increasing timber production and sustaining conservation values in natural tropical production forests. A systematic review protocol. Environ. Evidence, 4(8), 1-7, doi.org/10.1186/ s13750-015-0034-7

$\mathrm{R}$ Core Team, 2018. A language and environment for statistical computing. Vienna: $\mathrm{R}$ Foundation for Statistical Computing.

Rio D.M., Schütze G. \& Pretzsch H., 2014. Temporal variation of competition and facilitation in mixed species forests in Central Europe. Plant Biol., 16(1), 166-176, doi.org/10.1111/plb.12029

Sawitri et al., 2020. Potential of genome-wide association studies and genomic selection to improve productivity and quality of commercial timber species in tropical rainforest, a case study of Shorea platyclados. Forests, 11(2), 239, doi.org/10.3390/f11020239

Sotelo C., Hernández R.E., Beaulieu J. \& Weber J.C., 2008. Genetic variation in wood color and its correlations with tree growth and wood density of Calycophyllum spruceanum at an early age in the Peruvian Amazon. New For., 35(1), 57-73, doi.org/10.1007/s11056-0079060-9

Tieguhong J.C. et al., 2017. Beyond timber: balancing demands for tree resources between concessionaires and villagers. Int. For. Rev., 19(S2), 1-14, doi. org/10.1505/146554817822295966

Toledo M. et al., 2011. Climate is a stronger driver of tree and forest growth rates than soil and disturbance. J. Ecol., 99(1), 254-264, doi.org/10.1111/j.13652745.2010.01741.x

Uhl E. et al., 2015. Analysing the effect of stand density and site conditions on structure and growth of oak species using Nelder trials along an environmental gradient: experimental device, evaluation methods, and results. For. Ecosyst., 2(17), 1-19, doi.org/10.1186/s40663-0150041-8

Vanclay J.K., Lamb D., Erskine P.D. \& Cameron D.M., 2013. Spatially explicit competition in a mixed planting of Araucaria cunninghamii and Flindersia brayleyana. Ann. For. Sci., 70, 611-619, doi.org/10.1007/s13595013-0304-X

Vlam M. et al., 2014. Understanding recruitment failure in tropical tree species: insights from a tree-ring study. For. Ecol. Manage., 312, 108-116, doi.org/10.1016/j. foreco.2013.10.016

Wood S.N., 2011. Fast stable restricted maximum likelihood and marginal likelihood estimation of semiparametric generalized linear models. J. R. Stat. Soc., 73(1), 3-36, doi.org/10.1111/j.1467-9868.2010.00749.x

Zuur A.F. et al., 2009. Mixed effects models and extensions in ecology with $R$. New York, USA: Springer, doi: 10.1007/978-0-387-87458-6

(47 ref.) 

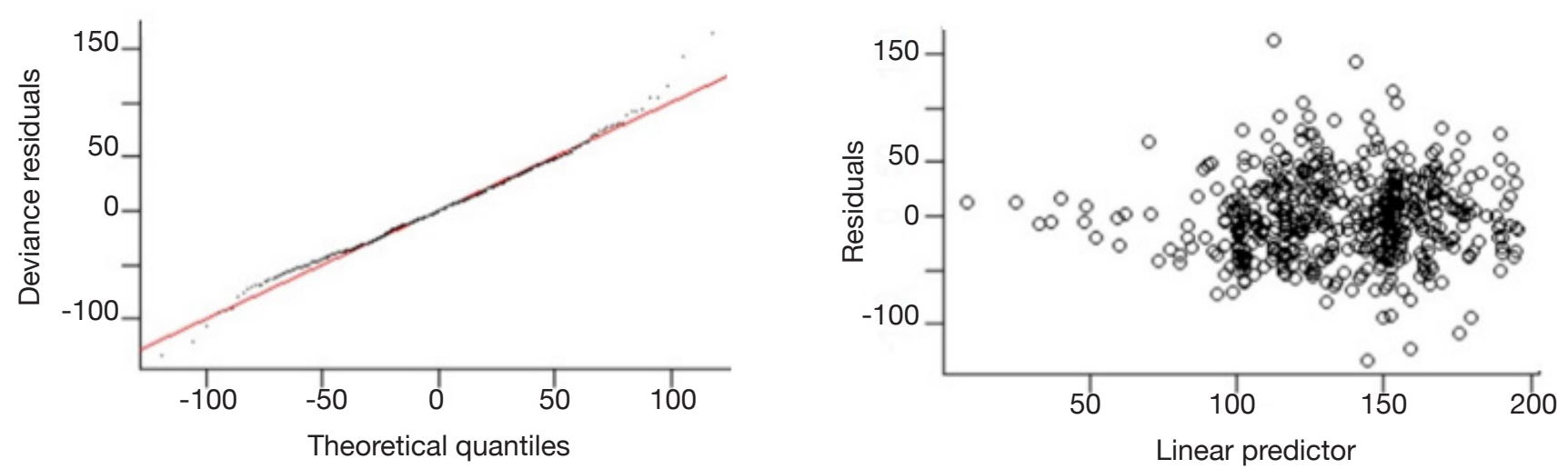

Appendix Figure A1. Residuals from the additive model used to model height increment - Résidus du modèle additif utilisé pour modéliser l'accroissement en hauteur.

Analysis of residuals showed that the conditions of normality and homoscedasticity were met - l'analyse des résidus a montré que les conditions de normalité et d'homoscédasticité étaient remplies.
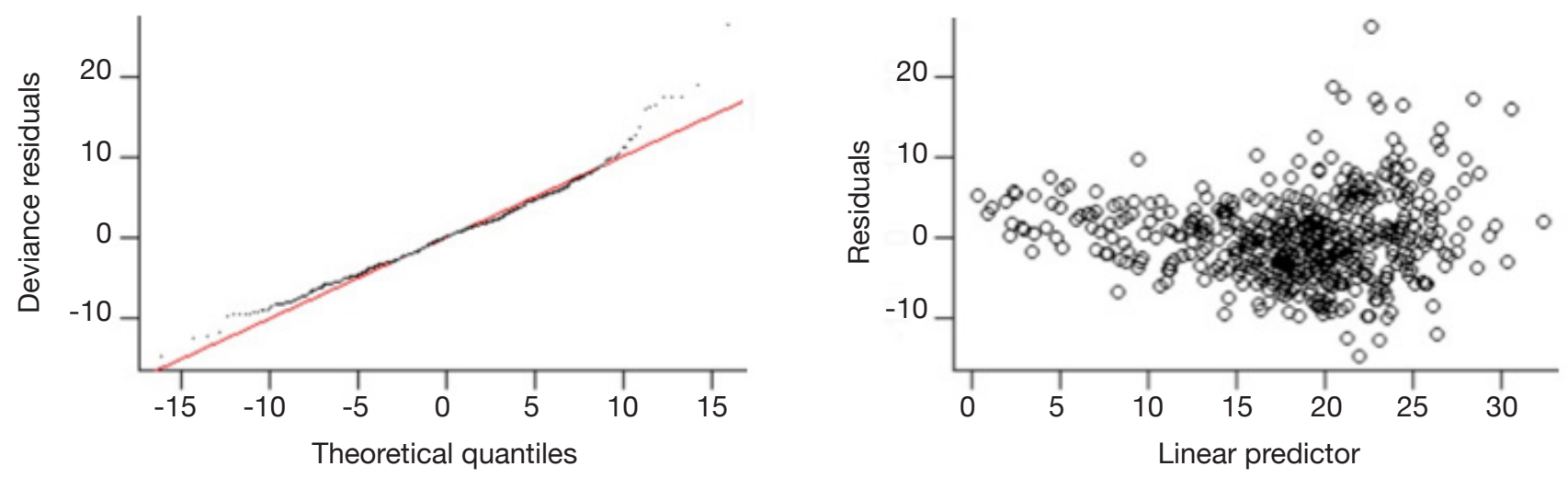

Appendix Figure A2. Residue of the additive model used to model growth in diameter - Résidus du modèle additif utilisé pour modéliser l'accroissement en diamètre.

Analysis of residuals showed that the conditions of normality and homoscedasticity were met - l'analyse des résidus a montré que les conditions de normalité et d'homoscédasticité étaient remplies. 